\title{
Credit Risk Management and Financial Performance: A Case of Bank of Africa (U) Limited
}

\author{
Ndyagyenda Catherine \\ Team University School of Graduate Studies \&Research Plot 446 Kabaka Anjagala Rd-Mengo, Kampala, Uganda \\ Email: ndyagendac@gmail.com
}

How to cite this paper: Catherine, N. (2020) Credit Risk Management and Financial Performance: A Case of Bank of Africa (U) Limited. Open Journal of Business and Management, 8, 30-38. https://doi.org/10.4236/ojbm.2020.81002

Received: July 22, 2019

Accepted: November 22, 2019

Published: November 25, 2019

Copyright ( 2020 by author(s) and Scientific Research Publishing Inc. This work is licensed under the Creative Commons Attribution International License (CC BY 4.0). http://creativecommons.org/licenses/by/4.0/

\section{Open Access}

\begin{abstract}
The study was meant to establish the relationship between credit risk management and financial performance of Bank of Africa (U) Ltd. The study adopted a case study approach and adopted both quantitative and qualitative approaches. The study established that the Bank has tried to diversify geographically not only within the country even though the majority of loans are granted to different regions within the country but also into neighboring countries like Tanzania. The bank has over 35 branches within the country among which 21 branches are in the central and 14 branches up country. Strong Credit Appraisal puts the milestones for an effective management of credit risk and gives the firms a competitive advantage in the market place. Hence it can be concluded that credit appraisal defines a bank's survival and profitability. The value of adjusted $\mathrm{R}$ Square was 0.978 , an indication that there was a variation of $97.8 \%$ on performance of the bank due to changes in client appraisal, credit risk control, and risk diversification at $95 \%$ confidence interval. The study recommends that the management of the Bank should continuously assess their risk management practices to see if they are still practical in the face of a continuously changing operating environment, for instance the new regulatory regimes. The products should be tailored towards the local language for easy understanding of the products. The study makes the original contribution by suggesting that there is a positive relationship between credit risk management and performance of the bank. These insights are useful for academic understanding and policy formulation by the decision makers of the bank.
\end{abstract}

\section{Keywords}

Credit Risk, Banks, Financial Performance 


\section{Introduction}

Today world over, Commercial Banks are the largest financial institutions with branches and subsidiaries throughout everyone's life. There are plenty of differentiations between types of banks. And much of this differentiation rests in the products and services that banks offer (Singh [1]). Commercial Banks are the major financial intermediaries in any economy and they are the major providers of credits to the household and corporate sector and operate the payment mechanism. They deal with both retail and corporate customers, have well diversified deposit and lending book and generally offer a full range of financial services (Aduda [2]). The aim of credit risk management is to minimize bank's risk adjusted rate of return by maintaining credit risk exposure within acceptable boundary. Banks need to manage the credit risk inherent in the entire loan portfolio as well as the risk in individual credit or transaction. Anderson 2012 [3] argues that Banks should also take into consideration the relationship between credit, liquidity, and interest rate risks.

\section{Literature Review}

\subsection{Theoretical Foundation of the Paper}

This section of the paper concentrates on the theoretical foundations and contributions of other scholars on the subject matter.

Credit is one of the many factors that can be used by a firm to influence demand for its products. According to Kaaya [4], firms can only benefit from credit if the profitability generated from increased sales exceeds the added costs of receivables. Credit is further defined as a process whereby possession of goods or services is allowed without spot payment upon a contractual agreement for later payment. Timely identification of potential credit default is important as high default rates lead to decreased cash flows, lower liquidity levels and financial distress. In contrast, lower credit exposure means an optimal debtor 'level with reduced chances of bad debts and therefore financial health. According to Krahnen [5] in today's business environment risk management and improvement of cash flows are very challenging. According to the Markowitz [6] credit risk refers to the risk that a borrower will default on any type of debt by failing to make payments which it is obliged to do. The risk is primarily that of a lender and includes lost principal and interest, disruption to cash flows, and increased collection costs. The loss may be complete or partial and can arise in a number of circumstances. Credit risk management is very important for banks as it gives an idea of how much exposure do, they have with counterparties vs. how much Counterparty exposure is there against the contracts. It is important to assess the counterparty risk and have some mitigation strategies in place.

Credit risk helps banks adjust their capital; deals in market considering the other party may default. Credit risk leads to market risk as it reduces liquidity of instruments and also to systemic risk. Thus, managers are advised to employ a modern risk management technique to diversify the earning activity of the bank. 


\subsubsection{The Effect of Risk Diversification on Financial Performance of the Bank}

This involves spreading investments into a broader range of financial services or loans; business, personal, credit cards, mortgage, auto and educational loans. Diversification reduces both upside and down side potential and allows for more consistent performance under a wide range of economic conditions. Diversification can be performed across products, industries and countries [7]. Diversification strategy probably takes place, when accompany or business organizations introduce a new product in the market. In early 1960's \& 1970's there is rapid growth in diversification of businesses. But with the passage of time it became difficult to manage much diversified activities of business organization. Even in recent years, it is quite hard for any business organization to operate in diversification mode because there are a lot of different requirements that must be taken into account by the business organization. Loan portfolio risk can be reduced with an effective credit review of applicants and selective asset backing. This paper aims at investigating the effect of diversification on financial performance of the Bank. This paper also attempts to use primary data in credit risk management which is a significant contribution in the area of finance.

\subsubsection{Risk Appraisal and Financial Performance}

Credit risk appraisal is the process by which the lender assesses the credit worthiness of the borrower. Procedures of credit appraisal: It revolves around character, collateral capability and capacity. It takes into account various factors like income of the applicants, number of dependents, monthly expenditure, repayment capacity, employment history, number of years of service and other factors which affect credit rating of the borrower [8].

The assessment of the various risks that can impact on the repayment of loan is credit appraisal. Depending on the purpose of loan and the quantum, the appraisal process may be simple or elaborate. For small personal loans, credit scoring based on income, lifestyle and existing liabilities may suffice. But for project financing, the process comprises technical, commercial, marketing, financial, managerial appraisals as also implementation schedule and ability. The credit risk appraisal involves measures employed by banks to avoid or minimize the adverse effect of credit risk.

\subsubsection{Risk Control Techniques in the Bank}

Credit control is the system used by a business to make sure that it gives credit only to customers who are able to pay, and that customers pay on time. Credit control is part of the financial controls that are employed by businesses particularly in manufacturing to ensure that once sales are made, they are realized as cash or liquid resources.

The institutional priorities, traditions and philosophies' surrounding lending or credit decisions play a more important role than ever in lending institutions Dasah [9]. Taking into consideration the complex and extensive nature of the 
banking business, it is essential to note that credit control embraces all the factors related to credit quality, credit extension, and recurrent cyclical patterns and sequences. Moreover, a disciplined and strong credit control represents the foundation of credit risk management since it guides all the credit and ending decisions.

\subsection{A Review of Related Empirical Literature}

A number of studies have been conducted on risk management. This section will review the empirical studies in view of the study. A robust risk management framework can help organizations to reduce their exposure to risks, and enhance their financial performance. Further it is argued that the selection of particular risk tools tends to be associated with the firm's calculative culture the measurable attitudes that senior decision makers display towards the use of risk management models. While some risk functions focus on extensive risk measurement and risk-based performance management, others focus instead on qualitative discourse and the mobilization of expert opinions about emerging risk issues (Mikes and Kaplan, 2014). .Kaaya and Pastory (2013) showed that credit risk indicators negatively affected on the bank performance. Ogboi [10], concluded that bank's financial performance had been affected by sound credit risk management and capital adequacy. Effective risk management is critical to any bank for achieving financial soundness. The indicator of Nonperforming loans had positive impact on banks profitability as measured by return on equity (ROE) and return on assets (ROA).

Poudel [11] analyzed the effect of financial risk management on the financial performance of commercial banks in Kenya. The study found out that majority of the Kenyan banks were practicing good financial risk management and as a result the financial risk management practices had a positive correlation to the financial performance of commercial banks in Kenya. The study recommended that banks should devise modern risk measurement techniques such as value at risk, simulation techniques and Risk-Adjusted Return on Capital. The study also recommended use of derivatives to mitigate financial risk as well as develop training courses tailored to the needs of banking personnel in risk management. Poudel [11] explored the various credit risk management indicators that affected banks' financial performance; he found out that the most indicators which affected the bank financial performance were the default rate. Credit risk is an internal determinant of bank performance. The higher the exposure of a bank to credit risk, the higher the tendency of the banks to experience financial crisis. In summary the important elements of managing risk include credit appraisal, diversification, credit control proper training of personnel. The effective credit policy is linked to the goals and measured against established metrics. A well-conceived credit policy helps the bank win good customers and avoid the time, cost and frustration of handling late paying customers thus increasing returns on asset loan and minimizing credit and fraud loses. 


\section{Methodology}

The research was based on quantitative research approach. A case study was chosen as the most appropriate research strategy. Descriptive research was used to collect detailed information, while analytical research has been used to analyze phenomenon. The main sources of data were financial reports, annual reports, text books, articles and company publications that included brochures and magazines. Questionnaires and interviews were also used to obtain the relevant data. The design was appropriate because of the nature of the study that required investigation of opinions and attitudes regarding credit risk management and financial performance.

The sampling procedure was both random and purposive. Data was presented using descriptive statistics involving frequency tables and percentages; data was also analyzed using SPSS version 20. Correlation and regression analysis were adopted to identify the relationship between the variables.

\section{Specifications of the Regression Variable}

The dependent variables of the sample are return on assets (ROA) and return on equity (ROE) which measure the profitability of the bank relatively to their assets. The independent variables are credit risk control, credit appraisal and, risk diversification.

\section{Findings}

\subsection{Descriptive Statistics}

From the findings, the study established that majority of the respondents strongly agreed that the bank motivates the staff to follow up the clients who take loans as shown by a mean of 3.53 and the standard deviation of 1.414, the bank has credit committee to follow up loans and non-performing assets as shown by a mean of 3.59 and standard deviation of 1.132 .

Imposing loan size limits is a viable strategy in credit risk management as shown by a mean of 3.69 and standard deviation of 1.256. The bank uses in house and outside experts/consultants from the banking industry to train the credit officers with a mean of 3.72 and standard deviation of 1.250.

The findings revealed that the bulk of the profits of commercial bank are not influenced by the amount of credit and non-performing loans, therefore suggesting that other variables other than credit. Relevant laws/regulations that affect lending activities improve financial performance of the bank as shown by a mean of 3.44 and standard deviation of 1.243 .

Most of the respondents agreed that the Manager makes sure that measures are in place to guard against credit card fraud to protect customers and the bank's investments as shown by a mean of 3.47 and standard deviation of 1.164, Loan to value is one of the key risk factors that lenders assess when qualifying borrowers for a mortgage. The risk of default is always at the forefront of lending decisions, and the likelihood of a lender absorbing a loss increases as the amount 
of equity increases with the mean of 3.53 and standard deviation of 1.191 . The study also established that, the bank spreads investments into a broader range of financial services or loans; business, personal, credit cards, mortgage, auto and educational loans to reduce credit risk as shown by a mean of 4.03 and standard deviation of 1.031 the bank diversifies geographically to reduce reliance on a particular region. As shown by a mean of 4.16 and standard deviation of 0.954 . The bank uses insurance and securitization as instruments of risk mitigation as shown by a mean of 4.31 and standard deviation of 1.091 and diversifies according to the type of customers to avoid credit risk with a mean of 4.37 and standard deviation of 1.008 .

These views are supported by Hagel, Brown and Davison who proposed that most economic analysts and investors tend to focus on return on equity as their primary measure of the bank's financial performance. ROE focuses on return to the shareholders of the company. If you are a shareholder, this gives you a quick and easy to understand metric. However, they argued that ROE can obscure a lot of potential problems. If investors are not careful, it can divert attention from business fundamentals and lead to spiteful surprises.

\subsection{Correlation between Credit Risk Management and Financial Performance}

Table 1 shows the relationship between Credit Risk Management (independent variable) and financial performance (dependent variable). It shows that the correlation between Credit Risk management and financial performance gives a multiple correlation coefficient $(\mathrm{R})=0.972$. This implies that there is a strong positive relationship between the two variables since $\mathrm{p}$-value is 0.000 which is less than 0.05 ( $\mathrm{p}<0.05$ ). It also means that Credit Risk Management influences financial performance of Bank of Africa by $97.2 \%$ and this confirms that there is a strong relationship between credit risk management and financial performance of Bank of Africa.

Table 1. Correlation between credit risk management and financial performance.

\begin{tabular}{|c|c|c|c|}
\hline & & $\begin{array}{c}\text { Credit Rick Management } \\
\text { (Risk Appraisal, } \\
\text { Risk Diversification } \\
\text { and Risk control) }\end{array}$ & $\begin{array}{c}\text { Financial Performance } \\
\text { (return on Asset and } \\
\text { Return on Equity) }\end{array}$ \\
\hline \multirow{3}{*}{$\begin{array}{c}\text { Credit Rick Management } \\
\text { (Risk Appraisal, Risk } \\
\text { Diversification and } \\
\text { Risk control) }\end{array}$} & $\begin{array}{c}\text { Pearson } \\
\text { Correlation }\end{array}$ & 1 & $0.972^{* *}$ \\
\hline & Sig. (2-tailed) & & 0.000 \\
\hline & $\mathrm{N}$ & 32 & 32 \\
\hline \multirow{3}{*}{$\begin{array}{l}\text { Financial Performance } \\
\text { (return on Asset and } \\
\text { Return on Equity }\end{array}$} & $\begin{array}{c}\text { Pearson } \\
\text { Correlation }\end{array}$ & $0.972^{* *}$ & 1 \\
\hline & Sig. (2-tailed) & 0.000 & \\
\hline & $\mathrm{N}$ & 32 & 32 \\
\hline
\end{tabular}

${ }^{* *}$ Correlation is significant at the 0.01 level (2-tailed). Source: Primary data. 


\subsection{Analysis of Regression Results}

\section{Model Fit}

Adjusted $\mathrm{R}$ squared is coefficient of determination which tells the variation in the dependent variable due to changes in the independent variable.

From the findings in Table 2 the value of adjusted R squared was 0.978 an indication that there was variation of $97.8 \%$ on performance of the bank due to changes in client appraisal, credit risk control and risk diversification at $95 \%$ confidence interval.

This shows that $97.8 \%$ changes in performance of Bank of Africa could be accounted for by client appraisal, credit risk control and risk diversification.

$\mathrm{R}$ is the correlation coefficient which shows the relationship between the study variables, from the findings shown in Table 3 there was a strong positive relationship between the study variables as shown by 0.990 . The table was statistically significant at $5 \%$ level since the $\mathrm{F}$ statistics have been 0.000 which proves the model to be significant.

From the data in Table 4 the established regression equation is as below.

Table 2. Model Summary of credit risk management and financial performance.

\begin{tabular}{ccccc}
\hline Model & R & R Square & Adjusted R Square & Std. Error of the Estimate \\
\hline 1 & $0.990^{\mathrm{a}}$ & 0.980 & 0.978 & 0.165
\end{tabular}

a. Predictors: (Constant), Credit Risk Control, Credit Appraisal, Risk Diversification. b. Dependent variable; financial performance.

Table 3. ANOVA for credit risk management and financial performance.

\begin{tabular}{ccccccc}
\hline & Model & Sum of Squares & Df & Mean Square & F & Sig. \\
\hline \multirow{3}{*}{1} & Regression & 36.783 & 3 & 12.261 & 450.626 & $0.000^{\mathrm{b}}$ \\
& Residual & 0.762 & 28 & 0.027 & & \\
& Total & 37.544 & 31 & & & \\
\hline
\end{tabular}

a. Dependent Variable: Financial Performance. Predictors: (Constant), Credit Risk Control, Credit Appraisal, Risk diversification. From the ANOVA statistics in table 4.9 above, the processed data, which is the population parameters, had a significance level of 0.00 which shows that the data is ideal for making a conclusion on the population's parameter as the value of significance (p-value) is less than $5 \%$. There is an indication that client appraisal, credit risk control and risk diversification significantly influence financial performance of Bank of Africa. The significance value was less than 0.05 indications that the model was statistically significant.

Table 4. Coefficients and significance level of the variable used.

\begin{tabular}{|c|c|c|c|c|c|c|}
\hline & \multirow{2}{*}{ Model } & \multicolumn{2}{|c|}{ Unstandardized Coefficients } & \multirow{2}{*}{$\frac{\text { Standardized Coefficients }}{\text { Beta }}$} & \multirow{2}{*}{$\mathrm{t}$} & \multirow{2}{*}{ Sig. } \\
\hline & & B & Std. Error & & & \\
\hline \multirow{4}{*}{1} & (Constant) & 0.148 & 0.199 & & 0.741 & 0.465 \\
\hline & Credit Appraisal & 0.373 & 0.249 & 0.354 & 1.496 & 0.146 \\
\hline & Risk Diversification & 0.024 & 0.281 & 0.022 & 0.087 & 0.932 \\
\hline & Credit Risk Control & 1.317 & 0.222 & 1.362 & 5.922 & 0.000 \\
\hline
\end{tabular}

a. Dependent Variable: Financial Performance. 


$$
\begin{aligned}
Y= & 0.148+0.373(\text { Client Appraisal })+0.024 \text { (Diversification }) \\
& +1.317(\text { Credit Risk Control })
\end{aligned}
$$

From the above regression equation it was revealed that holding client appraisal, risk diversification and credit risk control to a constant zero, performance of Bank of Africa would be 0.148 , a unit increase in client appraisal would lead to increase in performance of the bank by a factor of 0.373 , a unit increase in risk diversification would lead to increase in financial performance of the Bank by a factor of 0.024 and also unit increase in credit control would lead to increase in performance of the Bank by a factor of 1.317.

The study also found that p-values were less than 0.05an indication that all the variables were statistically significant in influencing the financial performance of Bank of Africa. This implies that at 5\% level of significance and 95\% level of confidence, credit appraisal, risk diversification and credit control all significantly influenced the financial performance of Bank of Africa.

\section{Conclusions}

It has been observed that the increase in credit risk tends to lower the banks financial performance in terms of profits, which is the primary goal of the bank through credit creation. The bank has to equitably allocate enough resources to empower the efforts of the credit risk management team and assets must be properly distributed to improve on the financial performance. The researcher observed that some accounts such as the Young Mullah and Teenz Tots are not so effective considering the nature of the Ugandans who do not have the habit of saving and also the low incomes of Ugandans including income inequality. This affects credit risk management and financial performance.

Products should be tailored towards the local language, client sensitization coupled with training of loan officers. The Credit Reference Berea (CRB) is not the best strategy to appraise the clients because it is not always updated; recent products are not wholly networked and thus misleading. Time for appraising the client should be extended for different clients according to the nature and size of the loan, sound management practices like good corporate governance should be adopted to reduce credit risk.

\section{Conflicts of Interest}

The author declares no conflicts of interest regarding the publication of this paper.

\section{References}

[1] Singh, A. (2013) Credit Risk Management Practices in Ghana Commercial Banks. International Journal of Marketing and Management Research, 2, 47-51.

[2] Aduda, J.A. (2011) The Relationship between Credit Risk Management and Profitability among Commercial Banks in Kenya. Journal of Modern Accounting and Auditing, 7, 934-946. 
[3] Anderson, F.A. (2010) A Strategic Framework for Governance, Risk and Compliance.

[4] Kaaya, I.A. (2013) Credit Risk and Commercial Banks Performance in Tanzania. Research Journal of Finance and Accounting, 4, 55-63.

[5] Krahnen, J.A. (2013) The Basel II Reform and Retail Credit Markets. Journal of Commercial Bank Lending, 36, 12-17.

[6] Markowitz, H. (1952) Portfolio Selection. Journal of Finance, 7, 77-97. https://doi.org/10.2307/2975974

[7] Kaplan, M.A. (2014) Theory of Entreprise Risk Management. White Paper, 1-45.

[8] Kithinji, A. (2010) Credit Risk Management and Profitability of Commercial Banks in Kenya. Working Paper.

[9] Dasah, J.A. (2012) Credit Risk and Profitability of Selected Banks in Ghana. Research Journal of Finance and Accounting, 3, 6-15.

[10] Ogboi, C.A. (2013) Impact of Credit Risk Management and Capital Adequacy on the Financial Performance of Commercial Banks. Journal in Finance and Banking, 2, 703-717.

[11] Poudel, R. (2012) The Impact of Credit Risk Management on Financial Performance of Commercial Banks in Napal. International Journal of Arts and Commerce, 1, 9-15. 